\title{
Falls among the elderly: environmental limitations and functional losses
}

Darkman Kalleu da Silva Teixeira' ${ }^{2}$ Luana Machado Andrade² (ID Jessica Lane Pereira Santos' ${ }^{10}$ Ediane Santos Caires' $\mathbb{1 D}$

\section{Abstract}

Objective: To identify the intrinsic and extrinsic factors that predispose the elderly to falls and to discuss the consequences of these events in their lives. Method: A descriptive, exploratory study with a qualitative approach was carried out in a city in the southwest region of Bahia, Brazil. The target audience was composed of elderly people living in the area covered by the Family Health Strategy of this city. Data collection took place from April to June 2018 through a semi-structured, scripted interview. The content analysis technique proposed by Laurence Bardin was used to analyze and organize the information. Results: From the analysis of the interviews the main factors that predisposed the elderly to falls emerged, and these were methodologically divided into intrinsic and extrinsic. There were also post-fall events, such as the fear of falling again and the need to inhabit the same place where the fall occurred, as this is a domestic environment which, for social reasons, cannot be modified as recommended by preventive educational actions. Conclusion: The results show that falls among these elderly people occurred in the domestic environment due to structural (extrinsic) issues, and are less influenced by health problems (intrinsic). It can therefore be concluded that the need to inhabit the same place where the fall occurred, without it being modified, generates a fear of falling again, limiting independence and reducing functional capacity, and making effective intersectoral actions essential.

\footnotetext{
1 Universidade do Estado da Bahia, Campus XII, Departamento de Educação. Guanambi, Bahia, Brasil.

2 Universidade Estadual do Sudoeste da Bahia, Campus Jequié, Departamento de Saúde II. Jequié, Bahia, Brasil.
}

Keywords: Accidental Falls. Aging. Health of the Elderly. 


\section{INTRODUCTION}

The rapid growth rate of the elderly Brazilian population has resulted in significant concerns in relation to one of the major events affecting this age group: falls. Such events are known to have multifactorial causes and high therapeutic complexity, as they are unintentional and result in the individual suffering an impact against the ground, and are caused by intrinsic and extrinsic factors. The phenomenon occurs mainly in the home environment, causing reductions in the mobility and independence of the elderly, the main outcome of which is a decrease in functional capacity, as well as an increase in personal and public expenses due to hospitalization after the event ${ }^{1}$.

Aging is considered a natural process, related to the functional impairment of the body that inevitably occurs over time. This change in functional capacity makes the elderly more vulnerable to the influence of extrinsic and intrinsic factors, as well as harm resulting from chronic noncommunicable diseases (NCDs) ${ }^{2}$.

Extrinsic factors are those involved in the interaction of the elderly with the environment in which they live, with the home the place of greatest exposure to risk, and include: slippery and uneven floors, the absence of support bars and handrails on stairs, objects scattered around the floor of the home, high steps, inadequate lighting, among others, increasing the possibility of irreversible events ${ }^{3,4}$.

Intrinsic factors, meanwhile, are considered health problems linked to the individual, and are related to biopsychosocial changes, reflected in their inability to balance when a displacement of their own height occurs. Examples are: dizziness; the use of medicines; muscle weakness; low visual and hearing acuity; change of gait; and acute diseases, among others ${ }^{4}$.

Falling is usually associated with the increased frailty and vulnerability of the individual. However, some risk behaviors, such as sedentarism and the lack of physical activity, may increase the risk of falls and further reduce functional capacity in old age. It is also worth mentioning that some mental and cognitive disorders, such as depression and dementia, linked to other comorbidities and postural instability, are also limiting in old age ${ }^{5}$.

Thus, as age advances, many older people become chronic users of medications to treat NCDs, defined as polypharmacotherapy, which arises from self-medication and iatrogenesis and is caused by ignorance of what it is most important to treat at this stage of life. The excess use of medications in everyday life is an important risk factor for the elderly, the result of which often causes prolonged hospitalization ${ }^{6}$.

The increased prevalence of falls in this population, resulting in hospitalizations, leads to increased public health spending and the use of hospital beds for longer. Thus, it is essential to seek more investment in actions of health promotion and fall prevention, such as the development of educational practices aimed at improving knowledge about the risks that these events may cause, with the aim of positively affecting the quality of life of this population?

It is important to remember that while anyone can suffer a fall, the consequence of this event is greater for the elderly as it influences their mobility and reduces functioning, leading to psychophysical, functional and economic changes. Considering the elderly and their caregivers in terms of the Family Health Strategy (FHS) is sometimes limiting due to the responsibility of performing actions to promote fall prevention training and orientation among this population ${ }^{8}$. The importance of the multiprofessional team in the hospital is also emphasized, in terms of preparation for discharge and the returning home of the elderly, aimed at alleviating post-fall syndrome.

Given the importance of this theme, the present study aimed to identify the intrinsic and extrinsic factors that predispose the elderly to falls, as well as to address the consequences of these events in their lives.

\section{METHOD}

A descriptive, exploratory study with a qualitative approach was carried out in a municipal district located in the southwest region of the state of Bahia, 
Brazil. The target audience of the study was elderly people living in the area covered by an FHS located in this municipal district.

The following inclusion criteria were chosen: elderly people who had suffered falls in the previous two years, given the limited period in which the issues important for the study could be recalled, who resided with their families or otherwise; who were registered with the FHS chosen for the study, and who if they could not communicate coherently, had a caregiver to assist with answering the questionnaire. Elderly persons who were not found at home on three consecutive visits were excluded. The elderly were intentionally selected through the Community Health Agents (CHA).

Ten elderly people participated in this study, and the criterion used to delimit the number of participants was data saturation. This indicates the moment when an increase in the data and/ or information of a study will not change the understanding of the studied phenomenon. This criterion allows the observing and validating of a certain recurrence of information?.

Data collection took place from April to June 2018, through a semi-structured interview script recorded with a voice recorder. This script addressed sociodemographic data, such as: location of fall, responsible factor (environmental and individual risks), amount of medications in daily use, postfall syndrome (fear of further falls), harm after the event suffered (reduced mobility, dependence on third parties, physical inactivity), frequent the same environment where the fall occurred, data on behaviors related to health, and modification of the environment where the event occurred. A field diary for the notes made from observing the environment in which the elderly suffered the fall was also used.

The thematic content analysis technique proposed by Laurence Bardin was used to analyze and organize the information obtained from the semi-structured interview, and consisted of three stages: pre-analysis, exploration of material and treatment of results, where the raw results were treated to make them meaningful and valid ${ }^{10}$. Therefore, the information was categorized into thematic axes that converged with the objective of this study.
In order to preserve the anonymity of the participants, the speech fragments were coded with the capital letter P (participant) followed by an ordinal number (P01, P02 and so forth), although not necessarily in the order of the interviews.

This study was approved by the Research Ethics Committee of the Universidade do Estado da Bahia under Opinion No. 2.540.677, respecting the ethical and scientific aspects proposed in Resolution No. 466/2012 of the National Health Council/MS on research involving human beings ${ }^{11}$.

After approval, contact was made with the FHS and, subsequently, the cooperation of $\mathrm{CHAs}$ was requested to identify the location of the homes of the elderly persons who had fallen. The interviewees were duly informed about the questions to be addressed by the research and the nature of their participation. After due clarification, a Free and Informed Consent Form (FICF) was signed by the elderly person or caregiver.

\section{RESULTS AND DISCUSSION}

The answers of the respondents were analyzed and information obtained from 10 participants. There was a predominance of females $(80.0 \%)$, aged between 62 and 90 years, with an average age of 75.1 years, showing the feminization of old age and its consequences ${ }^{12}$.

All the falls occurred at home, with a predominance in the bedroom and/or bathroom, with six $(60.0 \%)$ falls, followed by four $(40.0 \%)$ in the yard. Seven $(70.0 \%)$ elderly persons reported at least one falling episode in the previous year, one $(10.0 \%)$ reported two or more falls, while two $(20.0 \%)$ experienced only one fall, more than a year ago. Of the respondents, only two $(20.0 \%)$ elderly persons practiced physical activity regularly, such as cycling.

The content of the responses led to the understanding that falls in the elderly population assume various meanings that permeate intrinsic and extrinsic factors, extending to limiting consequences that affect the conduct of the elderly after the event in an integral manner. Based on the statements, the 
following units of meaning that most frequently emerged were identified: factors associated with recurrent falls in the elderly, both extrinsic and intrinsic, and post-fall consequences.

Due to the functional alterations involved in the aging process, falls become common events which are multifactorial in cause and are a concern for the elderly. They may cause a decline in physical capacity, frailty, gait speed reduction, greater risk of institutionalization and increasing hospitalization costs, and subsequently represent an important public health problem ${ }^{13}$.

Thus, when inserted in the community, there are numerous factors that increase the risk of the elderly suffering a fall, such as body and visual balance problems, polypharmacy, cognitive decline, muscle weakness, dizziness, a compromised environment in which the elderly must move around and the absence of a family caregiver or otherwise, among others ${ }^{14}$.

Regarding environment, falls occurred most frequently in the bathroom, making it a location susceptible to falls, since most homes did not have a suitable structure for the use of such rooms by the elderly. Slippery floors, the absence of non-slip mats or safety grab bars, inadequate lighting, and steps at the exit increase the risk of falls ${ }^{15}$.

After the bathroom, the yards of the homes of the elderly persons were significant in the episodes of falling in the present study. Research has shown that the structure of such environments presents major risk factors for the onset of falls, increasing the possibility of surgical interventions, especially those related to femoral fractures ${ }^{16}$.

Thus, the factors that led the elderly to fall most often were: the impairment and/or irregularity of the environment in which they lived; the use of three or more medications per day; frequent dizziness; reduced gait from other recurrent events; decreased visual acuity; chronic diseases; objects scattered on the floor of the residence and slips in the bathroom.

It important to highlight how intrinsic and extrinsic factors occur in this context through the statements of the participants. Chart 1 shows this comparison.

Chart 1. Representation of the intrinsic and extrinsic factors of the discourse of the interviewed elderly. Guanambi, Bahia, 2018.

\begin{tabular}{|c|c|}
\hline Extrinsic factors & Intrinsic Factors \\
\hline $\begin{array}{l}\text { "I was taking a shower, when suddenly, when I left the } \\
\text { bathroom, I missed the rug at the door and I slipped" (P07). }\end{array}$ & \multirow{2}{*}{$\begin{array}{l}\text { "The medicines are there, there's no way I can remember, } \\
\text { they so many medicines! Sometimes there are four, then } \\
\text { there were times there were five, today there are six, apart } \\
\text { from the insulin, with insulin there are seven" (P04). }\end{array}$} \\
\hline $\begin{array}{l}\text { "In the yard, when leaving the bathroom. I went out and } \\
\text { tripped on a rock, my legs aren't so good" (P03). }\end{array}$ & \\
\hline $\begin{array}{l}\text { "A pillar, two fingers thick, I fell down, like a step" } \\
\text { (P04). }\end{array}$ & $\begin{array}{l}\text { "It seems that I felt dizzy and there was nothing I could } \\
\text { do, if the girl (granddaughter) hadn't come I would have } \\
\text { died there" (P09). }\end{array}$ \\
\hline $\begin{array}{l}\text { "It happened when I was taking a shower and I don't } \\
\text { know what happened, I made it easy, my sandal slipped } \\
\text { in and I took a step backwards and fell, hitting my spine } \\
\text { on the toilet" (P11). }\end{array}$ & $\begin{array}{l}\text { "Three for blood pressure and two for diabetes, apart } \\
\text { from cholesterol which isn't here" (P06). }\end{array}$ \\
\hline $\begin{array}{l}\text { "The sandal got caught on the cement like this, going } \\
\text { upwards, and I tripped" (P06). }\end{array}$ & \multirow{3}{*}{$\begin{array}{l}\text { "I take several, two for blood pressure, two for cholesterol } \\
\text { and one for the heart, I'm not taking the one for diabetes, } \\
\text { one I have to fast and two I take at night, eight medicines, } \\
\text { because I took the diabetes one too" (P09). }\end{array}$} \\
\hline "When I went backwards, I slipped and fell" (P02). & \\
\hline $\begin{array}{l}\text { "I stumbled and slipped, I stumbled because of the step" } \\
\text { (P08). }\end{array}$ & \\
\hline $\begin{array}{l}\text { "I hit my head on the door and went backwards, there } \\
\text { was a ramp, I couldn't balance myself and I fell" (P10). }\end{array}$ & $\begin{array}{l}\text { "The dizziness isn't it, the dizziness!" } \\
\text { "For high blood pressure I take several, I take about six } \\
\text { medications a day" (P01). }\end{array}$ \\
\hline
\end{tabular}


Given the statements of the participants, the environmental risk factors, i.e. extrinsic factors, were identified as the main risk factors, increasing, in turn, the possibility of irreversible events occurring.

Based on the discourse of the participants, eight $(80.0 \%)$ elderly persons fell due to factors associated with the environment in which they lived, while two $(20.0 \%)$ fell due to adverse reactions such as symptoms of dizziness and/or those related to biological and psychosocial disorders, characterized as intrinsic factors.

In the present study, falls occurred most frequently in the bedroom and/or bathroom, which are considered the environments that the elderly most frequent in their homes. It was also observed that the main cause of falls in the yard of their homes was objects scattered on the ground, such as objects natural to the yard including plant pots, buckets, domestic animals and utensils. The irregularity of the ground in the yard represented $40.0 \%$ of falls.

A small number of the elderly investigated suffered falls because of intrinsic factors, and the use of various medications is a predominantly significant factor in these cases. Therefore, the use of antidepressants, antihypertensives, anxiolytics and antipsychotics may be associated with dizziness, instability, drowsiness, motor dysfunction, reflex impairment, loss of balance and slipping ${ }^{17,18}$.

This fact was evidenced in the statements of the participants, when the elevated consumption of medicines favored the occurrence of adverse events, as polypharmacy among the elderly is currently an important protagonist in such occurrences. Thus, while drug reactions occur, polypharmacotherapy represents an influence on recurrent falls in the elderly population ${ }^{19}$.

Therefore, in order to reduce the adverse events caused by medications, the importance of health professionals in care and drug management is highlighted, with regard to discussions and guidance for the elderly and the community, to develop strategies that minimize reactions and prevent the onset of recurrent falls.

Another issue pertinent to intrinsic factors concerns the reduction of the functional capacity of the body, which inevitably leaves the individual susceptible to the influence of disorders in balance stabilizers, representing postural instability, as well as the senility-based reduction in muscle mass, an example of sarcopenia, with consequent loss of strength, firmness and endurance ${ }^{20,21}$.

During the application of the questionnaire the elderly having fallen due to the impairment of reflexes and indicated the use of four or more medications, associating them with probable adverse reactions of polypharmacy. Thus, it is worth considering that for these reflexes, especially those that are protective, and which are already diminished due to the natural aging process, medications are a further aggravating factor ${ }^{22}$.

As well as presenting the factors that predispose the individual to falls, it was important to address the consequences that these events have on the lives of the elderly. A reduction in functional capacity, the fear of suffering other falls, the restriction of basic activities of daily living and, above all, the exposure to a greater risk of institutionalization, leading to an increased use of specialized services and generating high costs for public services, are important issues identified in this study and which corroborate other research on the theme $e^{23,24}$.

The reports revealed a need to frequent the same place where the fall occurred, as this was always a room in the home. The fact that they cannot change these rooms to prevent other events means they must live with the fear of falling again. Chart 2 explains this through the statements related to this category. 
Chart 2. Representation of fear of falling and need to frequent the same place, post-fall environmental changes, and decreased functional capacity. Guanambi, Bahia, 2018.

\begin{tabular}{|c|c|c|}
\hline Fear of falling & $\begin{array}{l}\text { Modification of environment post- } \\
\text { fall }\end{array}$ & Reduction of functional capacity \\
\hline $\begin{array}{l}\text { "I'm afraid of falling in the } \\
\text { bathroom. I'm afraid of it happening } \\
\text { again, because I already suffered } \\
\text { a fall and didn't change the } \\
\text { environment" (P11). }\end{array}$ & $\begin{array}{l}\text { "Yes, you have to take a shower, } \\
\text { comb your hair, go inside and } \\
\text { come back carefully, don't you?" } \\
\text { Environmental modification: "No, } \\
\text { I didn't do it, I just take care, right?" } \\
\text { (P01). }\end{array}$ & $\begin{array}{l}\text { "The job I did the most, reduced. } \\
\text { The damage is that my expenses } \\
\text { have increased, I pay more for the } \\
\text { medicines I buy because of the pain } \\
\text { of the accident I had in my leg, the } \\
\text { monthly expenses increased" (P07). }\end{array}$ \\
\hline $\begin{array}{l}\text { "I'm very afraid. Because it seems } \\
\text { that the pain is inside me and it } \\
\text { seems like it will happen again" } \\
\text { (P07). }\end{array}$ & $\begin{array}{l}\text { "I do go there, I do." Environmental } \\
\text { modification: "I didn't make any } \\
\text { changes, it's still the same" (P03). }\end{array}$ & $\begin{array}{l}\text { "The fall? It was just at the surgery. } \\
\text { The lack of memory, the lack of } \\
\text { balance" (P04). }\end{array}$ \\
\hline $\begin{array}{l}\text { "I was afraid of it happening again" } \\
\text { (P09). }\end{array}$ & $\begin{array}{l}\text { "Yeah, I go there! Because that's } \\
\text { how it is, you have to take a shower." } \\
\text { Environmental modification: "No, } \\
\text { it's still the same" (P09). }\end{array}$ & $\begin{array}{l}\text { "It was very bad for me because I } \\
\text { used to go to more places before" } \\
\text { (P06). }\end{array}$ \\
\hline $\begin{array}{l}\text { "We always have it, don't we? Fear! } \\
\text { We get to this age, any carelessness } \\
\text { or misstep and we risk a fall" (P08). }\end{array}$ & $\begin{array}{l}\text { "Yes, I go to the same bathroom." } \\
\text { Environmental modification: "I } \\
\text { didn't install any safety measures, the } \\
\text { bathroom is the same" (P11). }\end{array}$ & $\begin{array}{l}\text { "Yeah, after this fall I got really bad. } \\
\text { It seems that I got even weaker than } \\
\text { I already was" (P02). }\end{array}$ \\
\hline $\begin{array}{l}\text { "Yes, I'm afraid. Fear, because } \\
\text { anything we fall into, our legs are } \\
\text { weak" (P03). }\end{array}$ & $\begin{array}{l}\text { "In the yard, yes, there is no } \\
\text { other way. But no in other places, } \\
\text { today I can't even go to church." } \\
\text { Environmental modification: "No. } \\
\text { I didn't do anything in the yard, it's } \\
\text { still the same, the same" (P06). }\end{array}$ & $\begin{array}{l}\text { "After the fall I had to buy medicine, } \\
\text { I hurt my back and my arm got worse } \\
\text { because I was already injured" (P08). }\end{array}$ \\
\hline
\end{tabular}

The fear of suffering new falls $(80.0 \%)$ and the need to frequent the same place in which the fall occurred (60.0\%) generated a feeling of insecurity and frailty in the participants, which can be seen in the statements of participants 03,07 and 09.

The statements of participants 08 and 11 mentioned aging as a probable cause of falls, while at the same time no environmental modifications were made in the location following the fall.

Of the elderly persons who fell in the yards of their homes, four (40\%) also said they did not make any modifications to the environment, as it would involve replacing the surface or floor, and they described suffering from financial difficulties. Social issues cannot be ignored in this situation, representing an indirect aggravating factor for falls in elderly people from vulnerable communities in society.
Regarding the consequences after a fall, it was found that one adverse event can lead to others, which makes it difficult to maintain the functional capacity of these elderly persons, directly interfering with their quality of life. The first of these - the fear of falling syndrome - becomes a vicious circle, as the elderly fall ${ }^{25}$. In this study, the elderly portrayed their insecurity in an ambiguous manner, as while on the one hand it served to increase their concerns over maintaining balance after suffering a fall and prevented them from being injured again, on the other it showed that economic and social limitations are an obstacle to the adoption of preventive measures and changes in the environment in which they fell.

Research has shown that a sense of fear after a fall is a result of the deviation of attention, causing a reduction in the reception of stimuli and increased immobility and postural instability. Additionally, it 
allows individuals to restrict themselves from certain activities and therefore makes them susceptible to new fall events ${ }^{26,27}$.

In this sense, elderly persons become more apprehensive and less confident, thus limiting their performance in daily activities, which contributes to increased inactivity and a decline in functional capacity, which becomes more aggravated when the individual has difficulties in ambulation due to comorbidities $^{26,28}$.

Thus, psychosocial issues related to quality of life during old age also have a significant relationship with reduced muscle strength ${ }^{20}$. It was observed in the study that the fear of suffering further falls limited the basic activities of daily living of the elderly, making them sedentary and predisposing them to a decline in functional capacity, increasing the risk of future falls.

The elderly reported major limitations in their activities, such as impaired gait, causing a lack of balance, dependence on others, being restricted to wheelchairs, muscle weakness, using the telephone, taking care of finances, shopping, use of means of transport, difficulty and pain moving.

It was also observed that eight (80.0\%) elderly people remained sedentary, leading to reflections on whether this way of life is the cause or a consequence of a fall. Sedentarism presents a higher risk of falls, but the consequences of the event can also lead to a sedentary lifestyle due to fear, insecurity and the sequelae present ${ }^{29}$.

While not changing the frequency with which falls occur in the life of the elderly, certain measures that can make them less severe ${ }^{4}$. The recommendations of the World Health Organization (WHO) indicate the importance of modifying the home environment, the altering of habits and increased adherence to the proposed treatment of comorbidities, in order to prevent further falls, thus favoring the health of the elderly ${ }^{30}$.

There is therefore a need to implement measures that mitigate the risks of falls in households and, consequently, the health complications they cause.
Such risk factors should be established and guided by health professionals, both in the hospital environment (during preparations for discharge), as well as during consultations and/or visits by Primary Care health professionals, who should make the elderly person, caregivers and family members aware of them, and promote the reduction of the incidence of falls through changes that support the independence of this population.

Even in the homes of the elderly with lower purchasing power, where architectural and structural changes to the environment are impossible, health professionals can play a crucial role in providing guidance on how to provide a safe environment through the use of simple measures, such as avoiding the use of loose clothing and slippers, the presence of rugs, untidy environments and loose animals, among others, as well as encouraging the practice of physical exercise to strengthen the muscles of the elderly.

However, while recognizing and noting the need for environmental changes and physical activity in the prevention of falls, the limiting effect of the social conditions in which most of our elderly persons live cannot be ignored. It is therefore necessary to consider the importance of affirmative intersectoral actions aimed at minimizing the data provided by the inequities and inequalities in Brazil ${ }^{31}$.

Falls can reduce the functional capacity of the elderly, increasing the chances of further such events $^{32}$. Thus, the manner in which people age today is a concern, with losses in quality of life resulting in a consequent decrease in functional capacity and autonomy ${ }^{16}$.

The present study has certain limitations that should be mentioned. First, only participants who suffered falls in the previous two years were chosen, resulting in limited scope for the making of generalizations. However, this limitation does not make the study unfeasible, as the degree of saturation demonstrated the commonality of factors that led to the occurrence of the event. Although the highest incidence of falls was found in the female population, the present study included the participation of only two elderly men, limiting the results for this population. 


\section{CONCLUSION}

The results show that there is a greater prevalence of falls caused by the interaction between the elderly and the environment in which they live, than arise from the health problems of the individual. Therefore, extrinsic factors were more prevalent than intrinsic factors.

In the present study, falls occurred when walking and the main factors that led the elderly to fall were, respectively, impairments caused by the environment in which they lived or the irregularity of the same; the use of three or more medications per day; frequent dizziness; decreased gait due to other recurrent events; reduced visual acuity; chronic diseases; objects scattered on the floor of the residence and slipping in the bathroom.

Falls had emotional consequences, such as the fear of suffering new episodes; and functional effects, such as the impairment of gait, resulting in a lack of balance and being restricted to a wheelchair. In relation to this outcome, the elderly are forced to frequent the same place where the fall occurred without being able to adopt the recommended modifications in the rooms of their home. The social reality in which the majority of the elderly in Brazil eradicates the applicability of public policies, as without social support, there is no way to implement the same.

Therefore, it is up to health professionals, especially those in primary care, to develop measures that reduce the risk of falls in households and their complications, thus promoting actions that minimize the difficulties faced by the elderly, ranging from education to social issues.

With increased life expectancy, it is necessary for health professionals to think and reflect on educational activities that promote the autonomy and independence of the elderly population, in order to produce knowledge aimed at modifying life habits and environmental care strategies to reduce the risk of future falls and their consequences.

\section{REFERENCES}

1. Pereira-Llano PM, Santos F, Rodrigues MCT, Lemões MAM, Longe C, Santos SSC. The family in the care process of an elderly after a fall accident. Rev Pesqui Cuid Fundam [Internet]. 2016 [acesso em 22 nov. 2018];8(3):4717-24. Disponível em: https://www. redalyc.org/pdf/5057/505754106012.pdf

2. Brasil. Ministério da Saúde, Secretaria de Vigilância em Saúde, Departamento de Análise de Situação de Saúde. Plano de ações estratégicas para o enfrentamento das doenças crônicas não transmissíveis (DCNT) no Brasil 2011-2022 [Internet]. Brasília, DF: MS; 2011 [acesso em 22 nov. 2018]. Disponível em: bvsms.saude.gov.br/bvs/ publicacoes/plano_acoes_enfrent_dcnt_2011.pdf

3. Smith AA, Silva AO, Rodrigues RAP, Moreira MASP, Nogueira JA, Tura LFR. Avaliação do risco de quedas em idosos residentes em domicílio. Rev Latinoam Enferm [Internet]. 2017 [acesso em 07 de nov. 2018];25:e2754 [9 p.]. Disponível em: http://www.periodicos.usp.br/rlae/article/ download/130763/127143

4. Neto JAC, Brum IV, Braga NAC, Gomes GF, Tavares PL, Silva RTC, et al. Percepção sobre queda como fator determinante desse evento entre idosos residentes na comunidade. Geriatr Gerontol Aging [Internet]. 2017 [acesso em 07 de nov. 2018];11(1):25-31. Disponível em: http://www.ggaging.com/export-pdf/413/v11n1a05.pdf

5. Organização Mundial da Saúde. Relatório mundial de envelhecimento e saúde. Genebra: OMS; 2015 [acesso em 22 de nov. 2018]. Disponível em: https:// sbgg.org.br/wp-content/uploads/2015/10/OMSENVELHECIMENTO-2015-port.pdf

6. Santos BSM, Junior FJGS, Galiza FT, Lima LAA, Veloso C, Monteiro CFS. Polifarmácia entre idosos hospitalizados em um serviço público de referência. Rev Enferm UFPI [Internet]. 2016 [acesso em 22 de nov. 2018];5(1):60-6. Disponível em: http://www.ojs. ufpi.br/index.php/reufpi/article/view/4996/pdf

7. Andrade IR, Souza EA, Luz LA, Pinto Júnior EP. Características e gastos com hospitalizações por quedas em idosos na Bahia. J Health Sci Inst [Internet]. 2017 [acesso em 22 nov. 2018];35(1):28-31. Disponível em: https://www.unip.br/presencial/ comunicacao/publicacoes/ics/edicoes/2017/01_janmar/V35_n1_2017_28a31.pdf 
8. Oliveira PP, Oliveira AC, Dias AR, Rocha FCV. Caregiver's knowledge about prevention of falls in elderly. Rev Enferm UFPE on line [Internet]. 2016 [acesso em 2018 nov. 22];10(2):585-92.

Disponível em: https://periodicos.ufpe.br/revistas/ revistaenfermagem/article/download/10993/12346

9. Thiry-Cherques HR. Saturação em pesquisa qualitativa: estimativa empírica de dimensionamento. Rev Bras Pesqui Market Opin Mídia [Internet]. 2009 [acesso em 27 out. 2018];4(3):20-7. Disponível em: https://docplayer.com.br/15061-Saturacaoem-pesquisa-qualitativa-estimativa-empirica-dedimensionamento.html

10. Bardin L. Análise de conteúdo. Pinheiro. São Paulo: Edições 70, 2011.

11. Brasil. Ministério da Saúde, Conselho Nacional de Saúde. Resolução n²466 de dezembro de 2012. Aprova diretrizes e normas regulamentadoras de pesquisa envolvendo seres humanos. Brasília, DF: MS; 2012. Disponível em: http://bvsms.saude.gov.br/bvs/ saudelegis/cns/2013/res0466_12_12_2012.html

12. Almeida AV, Mafra SCT, Silva EP, Kanso S. A feminização da velhice: em foco as características socioeconômicas, pessoais e familiares das idosas e o risco social. Textos \& Contextos (Porto Alegre) [Internet]. 2015 [acesso em 20 Maio 2019];14(1):11531. Disponível em: https://www.redalyc.org/ pdf/3215/321540660010.pdf

13. Barros IFO, Pereira MB, Weiller TH, Anversa ETZ. Internações hospitalares por quedas em idosos brasileiros e os custos correspondentes no âmbito do Sistema Único de Saúde. Rev Kairós [Internet]. 2015 [acesso em 02 jul. 2019];18(4):63-80. Disponível em: http://ken.pucsp.br/kairos/article/ download/26930/19124

14. Oliveira AS, Trevizan PF, Bestetti MLT, Melo RC. Fatores ambientais e risco de quedas em idosos: revisão sistemática. Rev Bras Geriatr Gerontol [Internet]. 2014 [acesso em 02 jul. 2019];17(3):637-45. Disponível em: https://www.redalyc.org/pdf/4038/403838839016.pdf

15. Cavalcante DPM, Silva LJ, Matos N, Borges I, Araújo DP, Pinheiro HA. Perfil e ambiente de idosos, que sofreram quedas, atendidos em um ambulatório de Geriatria e Gerontologia no Distrito Federal. Rev Kairós [Internet]. 2015 [acesso em 07 nov. 2018];18(1):93-107. Disponível em: https://revistas. pucsp.br/kairos/article/download/23890/17135

16. Soares DS, Mello LM, Silva AS, Nunes AA. Análise dos fatores associados a quedas com fratura de fêmur em idosos: um estudo caso-controle. Rev Bras Geriatr Gerontol [Internet]. 2015 [acesso em 07 de nov. 2018];18(2):239-48. Disponível em: https://www. redalyc.org/pdf/4038/403842247002.pdf
17. Dyks DSC, Sadowski CA. Interventions to Reduce Medication-Related Falls. CME [Internet]. 2015 [acesso em 07 nov. 2018];5(1):23-31. Disponível em: http:// www.rgpeo.com/media/69639/dyks\%20article.pdf

18. Ferreira LMBM, Roigi JJ, Andrade FLJP, Oliveira NPD, Araújo JRT, Lima KC. Prevalência de quedas e avaliação da mobilidade em idosos institucionalizados. Rev Bras Geriatr Gerontol [Internet]. 2016 [acesso em 07 nov. 2018];19(6):995-1003. Disponível em: https:// www.redalyc.org/pdf/4038/403849869012.pdf

19. Cremer E, Galdino MJQ, Martins JT. Implicações da polimedicação em idosos portadores de osteoporose. J Nurs Health [Internet]. 2017 [acesso em 29 maio 2019];7(1):78-88. Disponível em: https://periodicos.ufpel.edu.br/ojs2/index.php/ enfermagem/article/viewFile/8884/7093

20. Matos FS, Jesus CS, Carneiro JAO, Coqueiro RS, Fernandes MH, Brito TA. Redução da capacidade funcional de idosos residentes em comunidade: estudo longitudinal. Ciênc Saúde Colet [Internet]. 2018 [acesso em 29 maio 2019];23(10):3393-3401. Disponível em: http://www.scielo.br/pdf/csc/ v23n10/1413-8123-csc-23-10-3393.pdf

21. Garcias PA, Dias JMD, Rocha ASS, Almeida NC, Macedo OG, Dias RC. Relação da capacidade funcional, força e massa muscular de idosas com osteopenia e osteoporose. Fisioter Pesqui [Internet]. 2015 [acesso em 29 maio 2019];22(2):126-32.

Disponível em: http://www.periodicos.usp.br/fpusp/ article/download/103916/102446

22. Cunha P, Pinheiro LC. O papel do exercício físico na prevenção das quedas nos idosos: uma revisão baseada na evidência. Rev Port Med Geral Fam [Internet]. 2016 [acesso em 07 nov. 2018];32:96-100. Disponível em: http://www.scielo.mec.pt/pdf/rpmgf/ v32n $2 / v 32 \mathrm{n} 2 \mathrm{a} 03 . \mathrm{pdf}$

23. Menezes C, Vilaça KHC, Menezes RL. Falls and quality of life of people with cataracts. Rev Bras Oftalmol [Internet]. 2016 [acesso em 29 maio 2019];75(1):40-4. Disponível em: http://www.scielo. br/pdf/rbof/v75n1/0034-7280-rbof-75-01-0040.pdf

24. Neto AHA, Patrício ACFA, Ferreira MAM, Rodrigues BFL, Santos TD, Rodrigues TDB, et al. Quedas em idosos institucionalizados: riscos, consequências e antecedentes. Rev Bras Enferm [Internet]. 2017 [acesso em 29 maio 2019];70(4):719-25. Disponível em: https:// www.redalyc.org/pdf/2670/267052023008.pdf

25. Gasparotto LPR, Falsarella GR, Coimbra AMV. As quedas no cenário da velhice: conceitos básicos e atualidades da pesquisa em saúde. Rev Bras Geriatr Gerontol [Internet]. 2014 [acesso em 07 de nov. 2018];17(1):201-9. Disponível em: https://www. redalyc.org/pdf/4038/403838834019.pdf 
26. Young WR, Williams AM. How fear of falling can increase fall-risk in older adults: applying psychological theory to practical observations. Gait Posture [Internet]. 2015 [acesso em 07 nov. 2018];41(1):7-12. Disponível em: https:// www.sciencedirect.com/science/article/pii/ S096663621400705X/pdfft?md5=dccf962 b15cf482275596aa9f6f27082\&pid=1-s2.0S096663621400705X-main.pdf

27. Lopes KT, Costa DF, Santos LF, Castro DP, Bastone AC. Prevalência do medo de cair em uma população de idosos da comunidade e sua correlação com mobilidade, equilíbrio dinâmico, risco e histórico de quedas. Rev Bras Fisioter [Internet]. 2009 [acesso em 07 nov. 2018];13(3):223-9. Disponível em: http:// www.scielo.br/pdf/rbfis/2009nahead/aop024_09.pdf

28. Antes DL, Schneider IJC, Benedetti TRB, D'orsi E. Medo de queda recorrente e fatores associados em idosos de Florianópolis, Santa Catarina, Brasil. Cad Saúde Pública [Internet]. 2013 [acesso em 07 nov. 2018];29(4):758-68. Disponível em: https://www. scielosp.org/pdf/csp/2013.v29n4/758-768/pt
29. Abdala RP, Júnior WB, Júnior CRB, Gomes MM. Padrão de marcha, prevalência de quedas e medo de cair em idosas ativas e sedentárias. Rev Bras Med Esporte [Internet]. 2017 [acesso em 06 jul. 2019];23(1):26-30. Disponível em: http://www.scielo. br/pdf/rbme/v23n1/1517-8692-rbme-23-01-00026.pdf

30. World Health Organization. Ageing and Life Course, Family and Community Health. WHO global report on falls prevention in older age. França: WHO; 2007 [acesso em 07 nov 2018]. Disponível em: https:// www.who.int/ageing/publications/Global_age_ friendly_cities_Guide_English.pdf

31. Guesdes MBOG, Lima KC, Caldas CP, Veras RP. Apoio social e o cuidado integral à saúde do idoso. Physis [Internet]. 2017 [acesso em 20 Maio 2019];27(4):1185-1204. Disponível em: https://www. scielosp.org/pdf/physis/2017.v27n4/1185-1204/pt

32. Falsarella GR, Gasparotto LPR, Caimbra AMV. Quedas: conceitos, frequências e aplicações à assistência ao idoso: revisão da Literatura. Rev Bras Geriatr Gerontol [Internet]. 2014 [acesso em 07 nov. 2018];17(4):897-910. Disponível em: https://www. redalyc.org/pdf/4038/403838840019.pdf 